\title{
A krónikus fájdalom lehetséges rizikótényezői és következményei a magyar tizenévesek körében
}

\author{
Godó Kinga dr. ${ }^{1^{*}}$ - Major János dr..$^{2,3^{*}}$ \\ Gyimesi-Szikszai Andrea dr. ${ }^{2}$ - Ádám Szilvia dr. ${ }^{3,4}$ \\ ${ }^{1}$ Ezüstkehely Gyógyszertár, Székesfehérvár \\ ${ }^{2}$ A Magyar Református Egyház Bethesda Gyermekkórháza, Fájdalomterápiás Ambulancia, Budapest \\ ${ }^{3}$ Semmelweis Egyetem, Mentális Egészségtudományok Doktori Iskola, Budapest \\ ${ }^{4}$ Semmelweis Egyetem, Egészségügyi Menedzserképző Központ, Budapest
}

\begin{abstract}
Bevezetés: A krónikus fájdalom prevalenciája nemzetközi adatok alapján $25 \%$ a tizenévesek körében, és a rossz életminőség mellett gyakran társul az egészségügy kiterjedt használatával és túlzott gyógyszerfogyasztással. Kevés magyarországi adat áll rendelkezésre a gyógyszerszedés gyakoriságáról és a krónikus fájdalommal való összefüggéseiről. Célkitüzés: A krónikus fájdalom prevelanciájának és lehetséges szociodemográfiai rizikófaktorainak, valamint a gyógyszerszedést befolyásoló tényezőknek a vizsgálata magyar tizenévesek körében.

Módszer: Keresztmetszeti epidemiológiai, kérdőíves vizsgálatot végeztünk budapesti 4, 6 osztályos gimnáziumokban és általános iskolákban 354 diák bevonásával. A demográfiai mutatók mellett vizsgáltuk a krónikus fájdalom jellemzőit, az egészségügyi rendszer használatát, valamint a gyógyszerszedési szokásokat.

Eredmények: A vizsgált személyek 31,1\%-a $(\mathrm{n}=110)$ szenvedett krónikus fájdalomban. A leggyakoribb fájdalom a végtagi fájdalom volt, amelyet gyakoriságban a fejfájás követett. A tizenévesek $4,6 \%$-ának $(\mathrm{n}=5)$ folyamatos fájdalma volt. A fiúk $\left(\chi^{2}=9,4 ; p=0,002\right)$ és a fiatalabb életkorú (Mann-Whitney $U=10906,5 ; p=0,004$ ) alanyok körében szignifikánsan alacsonyabb volt a krónikus fájdalom gyakorisága. Krónikus fájdalom esetén az alvászavar szignifikánsan gyakoribb volt $\left(\chi^{2}=8,9 ; \mathrm{p}=0,03\right)$. A fájdalom fennállási ideje, erőssége, gyakorisága és időtartama egyenes arányú szignifikáns kapcsolatot mutatott az orvoshoz fordulás prevalenciájával. A megkérdezettek $78 \%$-a $(\mathrm{n}=276)$ szedett gyógyszert a megelőző hat hónapban, ugyanakkor a rendszeresen gyógyszert szedők aránya is $48,3 \%$ volt ( $\mathrm{n}=171)$. A gyógyszerhasználat valószínúségét a magasabb életkor, a női nem, valamint a krónikus fájdalom megléte növelte. A krónikus fájdalommal élők körében szignifikánsan magasabb, fájdalom miatt történt gyógyszerfogyasztást igazoltunk $(\mathrm{n}=83,0,75,5 \%)$.

Következtetés: A nemzetközi eredményekhez hasonlóan a krónikus fájdalom, a gyógyszerszedés és az orvoshoz fordulás prevalenciája a magyarországi tizenévesek körében is számottevő, ami jelentős egészségügyi problémát jelent felnőttkorig terjedő hatásokkal.
\end{abstract}

Orv Hetil. 2020; 161(13): 502-509.

Kulcsszavak: adolescens, krónikus fájdalom, fejfájás, gyógyszerszedés

\section{Potential risk factors and consequences of chronic pain among Hungarian adolescents}

Introduction: Based on international data, the prevalence of chronic pain is $25 \%$ among adolescents which is associated with poor quality of life, extensive use of healthcare, and overuse of pain medication. Little is known about the medication use and chronic pain in Hungary.

Aim: To assess the prevalence and potential socio-demographic risk factors of chronic pain and medication use among Hungarian adolescents.

Method: We conducted a cross-sectional epidemiological study at primary and secondary schools with 354 schoolchildren. Adolescents responded to questionnaires about demographic variables, characteristics of chronic pain, use of health-care system and medication. 
Results: 110 adolescents (31.1\%) suffered from chronic pain in our sample. Pain in extremities was the most prevalent pain type. $4.6 \%(\mathrm{n}=5)$ of children suffered from continuous pain. The prevalence was lower among boys $\left(\chi^{2}=9.4\right.$; $\mathrm{p}=0.002$ ) and younger subjects (Mann-Whitney $\mathrm{U}=10906.5 ; \mathrm{p}=0.004$ ). Sleep disorder was more frequent among adolescents with chronic pain $\left(\chi^{2}=8.9 ; \mathrm{p}=0.03\right)$. Time from onset, intensity, prevalence and duration of pain were associated with the prevalence of visits to physicians. $78 \%(n=276)$ of the sample took medication in the previous 6 months, however, regular medication use was as high as $48.3 \%(n=171)$. We found a significant association between medication use and older age, female sex, and the presence of chronic pain. Medication use against pain among adolescents with chronic pain was significantly higher $(\mathrm{n}=83.0,75.5 \%)$.

Conclusion: The prevalence of chronic pain, medication use and visits to physicians is considerable among Hungarian adolescents. It is an important healthcare challenge with long-term consequences until adulthood.

Keywords: adolescent, chronic pain, headache, medication use

Godó K, Major J, Gyimesi-Szikszai A, Ádám Sz. [Potential risk factors and consequences of chronic pain among Hungarian adolescents]. Orv Hetil. 2020; 161(13): 502-509.

(Beérkezett: 2019. október 18.; elfogadva: 2019. december 8.)

\section{Rövidítések}

IASP $=($ International Association for the Study of Pain $)$ Nemzetközi Fájdalomkutató Társaság; NRS = (numeric rating scale) numerikus értékelőskála; OTC = (over the counter) vény nélkül kapható (készítmény)

A krónikus fájdalom a Nemzetközi Fájdalomkutató Társaság (IASP) definíciója alapján olyan fájdalom, amely legalább három hónapja fennáll, vagy a normál gyógyulási idôn túl is jelen van [1]. A krónikus fájdalom folyamatos és visszatérő egyaránt lehet, a gyermekek 25\%-át érinti különböző mértékben [2]. Gyermekkorban a leggyakoribb típus a fejfájás, ezt követi gyakoriságban a hasi fájdalom, a derék-, valamint a musculoskeletalis fájdalom. Lányok körében a prevalencia magasabb; az életkor növekedésével párhuzamosan a krónikus fájdalom gyakorisága mindkét nemben emelkedik. A kórkép jelentősen befolyásolhatja a gyermekek iskolai és mindennapi teljesítőképességét, így a testi, pszichés és szociális fejlődésre és a későbbi munkaképességre is jelentős negatív hatást gyakorol [3].

A fájdalom kialakulásában és fenntartásában a testi tényezőkön túl a pszichoszociális tényezőknek is szerepük van; ezek közül kiemelendő az alacsonyabb szocioökonómiai státusz, valamint az alvászavar, ugyanakkor a válás nem befolyásolta a kórkép prevalenciáját [2-4].

A gyermekpopuláció 5,1\%-a az életvitelt súlyosan korlátozó krónikus fájdalomban szenved, gyakran hiányzik az iskolából, szociális élete beszúkül, és körükben jelentôsen megnő a szorongásos és depresszív tünetek gyakorisága [4]. A súlyos állapotra jellemző az egészségügyi rendszer kiterjedt igénybevétele és a rendszeres fájdalomcsillapító-használat.

Perquin és mtsai vizsgálata alapján a krónikus fájdalommal élő gyermekek 57\%-a fordul orvoshoz, és 39\%-uk szed valamilyen fájdalomcsillapító gyógyszert a fájdalom enyhítésére. A tanulmány azt is igazolta, hogy a gyako- ribb és erôsebb fájdalom növelte az orvoshoz fordulás, a fájdalom intenzitása pedig a gyógyszerszedés valószínűségét [5]. Egy németországi reprezentatív vizsgálat szerint a magasabb anyai iskolai végzettség és a jobb szocioökonómiai helyzet kedvez a gyógyszerszedés kialakulásának [6].

A gyógyszerszedés magyarországi adatok alapján is jelentős egészségügyi probléma. Költô 2014-ben tizenéves korú iskolásokon végzett vizsgálata alapján a kamaszok 50\%-a vett be legalább egyszer gyógyszert az azt megelőző hónapban fejfájás ellen, ami Költő és Kökönyei 2011 -es vizsgálati adataihoz képest 8\%-os emelkedést jelent [7].

Az öngyógyszerezés gyakorlata messze nem mondható biztonságosnak. A helytelen öndiagnózis, az orvosi szakvélemény kikérésének elmulasztása, a gyógyszer-interakciók kialakulása, a nem megfelelő dozírozás vagy a dependencia kialakulása súlyos egészségkárosodáshoz vezethet [8].

Felnőttmintán történt vizsgálat alapján a vallásosság pozitívan befolyásolhatja a fájdalommal való megküzdést, ezt azonban adolescenskorban, illetve a gyógyszerszedés összefüggésében ez idáig még nem vizsgálták [9].

Jelen vizsgálatunkban célul tűztük ki a 12 és 18 év közötti magyar diákok körében a krónikus fájdalom prevalenciájának, valamint gyógyszerszedési szokásainak felmérését, a krónikus fájdalom különböző jellemzőinek, illetve a gyógyszerszedési szokásokkal való kapcsolatának vizsgálatát, tekintettel arra, hogy korábban e területen ilyen vizsgálat nem történt.

A fent bemutatott eddigi tudományos eredmények alapján hipotéziseink a következők voltak:

Hl.: A krónikus fájdalom és a gyógyszerszedés prevalenciája az idősebb tizenéves lányok körében gyakrabban, vallásos gyermeknél ritkábban jelentkezik, a gyógyszerszedés ugyanakkor a magasabb iskolai végzettségû anyák körében gyakoribb. 
H2 :: A krónikus fájdalom növeli az alvászavar valószínüségét, és a leggyakrabban fejfájásként jelentkezik.

H3.: Az orvoshoz fordulás gyakoriságát a gyakrabban jelentkező és erősebb fájdalom növeli.

H4.: A gyógyszerszedés valószínúségét az erôs és a gyakran jelentkező fájdalom, valamint a fejfájás növeli.

\section{Módszer}

\section{Minta}

Vizsgálatunkat 2017 májusában végeztük 480 diák bevonásával, akik közül 354-en (73,75\%) töltötték ki a kérdőíveket. A résztvevők a Budapesti Fazekas Mihály Gyakorló Általános Iskola és Gimnázium, a Kossuth Lajos Gimnázium, a Lázár Vilmos Általános Iskola és a Veres Pálné Gimnázium 7-12. osztályos tanulói voltak. A vizsgálatban való részvétel önkéntes volt, a gyermekek szülői beleegyezés után töltötték ki a kérdőívet. A vizsgált osztályokat véletlenszerüen úgy választottuk ki, hogy az általános iskola, a hat- és négyosztályos gimnázium minden évfolyamából vegyen részt diák a kutatásban.
A minta epidemiológiai jellemzőit az 1 . táblázat mutatja be.

A kutatást az Egészségügyi Tudományos Tanács Tudományos Etikai Bizottságának jóváhagyásával végeztük (engedélyszám: 27527-2017/EKU).

\section{Méröeszközök}

A vizsgált gyermekeknél a demográfiai mutatók közül a nemre, az életkorra, a lakóhelyre, a szülők kapcsolatára, az anya iskolai végzettségére és a gyermek vallásosságára kérdeztünk rá („Tartozol-e valamilyen vallási közösséghez, melynek programjaira rendszeresen eljársz?"). A demográfiai mutatók mellett a gyermekek alvászavarára is vonatkozott kérdés.

Vizsgálatunk a tizenévesek fájdalmát is jellemezte. A fájdalom helyére, intenzitására, fennállásának idejére, gyakoriságára, a panaszok időtartamára kérdeztünk rá azoknál, akiknek volt fájdalmuk az elmúlt 3 hónapban. A fájdalom intenzitásának becslésére a 0 -tól 10 -ig terjedő numerikus értékelőskálát (NRS) alkalmaztuk [10].

1. táblázat |A minta epidemiológiai jellemzői és az alvászavar prevalenciája

\begin{tabular}{|c|c|c|c|c|}
\hline & $\begin{array}{c}\text { Összesen } \\
\mathrm{n}(\%)\end{array}$ & $\begin{array}{c}\text { Krónikus fájdalommal élők } \\
\text { n (\%) }\end{array}$ & $\begin{array}{c}\text { Kontroll } \\
\mathrm{n}(\%)\end{array}$ & Statisztika \\
\hline Összesen & $354(100)$ & $110(31,1)$ & $244(68,9)$ & \\
\hline Nem & & & & $\chi^{2}=9,4 ; p=0,002$ \\
\hline Fiú & $188(53,1)$ & $47(42,7)$ & $141(57,8)$ & \\
\hline Lány & $166(46,9)$ & $63(57,3)$ & $103(42,2)$ & \\
\hline Átlagéletkor (SD) & $15,76(1,9)$ & $17,39(1,3)$ & $15,02(1,6)$ & Mann-Whitney U-teszt $=10906,5 ; \mathrm{p}=0,004$ \\
\hline \multicolumn{5}{|l|}{ Lakhely } \\
\hline Falu & $4(1,1)$ & $3(2,7)$ & $1(0,4)$ & $\mathrm{NSz}$ \\
\hline Község & $14(4,0)$ & $4(3,6)$ & $10(4,1)$ & $\mathrm{NSz}$ \\
\hline Kisváros & $28(15,0)$ & $25(22,7)$ & $28(11,5)$ & $\mathrm{NSz}$ \\
\hline Megyeszékhely & $2(06 \%)$ & $0(0,0)$ & $2(0,6)$ & $\mathrm{NSz}$ \\
\hline Fốváros & $281(79,4)$ & $78(70,9)$ & $203(83,2)$ & $\mathrm{NSz}$ \\
\hline Szülők kapcsolata & & & & $\mathrm{NSz}$ \\
\hline Házas, együttélés & $279(79,2)$ & $83(76,2)$ & $196(80,7)$ & \\
\hline Elvált & $73(20,7)$ & $26(23,9)$ & $47(19,3)$ & \\
\hline Anya iskolai végzettsége & & & & $\mathrm{NSz}$ \\
\hline 8 általános & $1(0,3)$ & $0(0,0)$ & $1(0,3)$ & \\
\hline gimnázium & $63(18,2)$ & $18(16,7)$ & $45(18,9)$ & \\
\hline Felsőfokú tanulmányok & $282(80,5)$ & $90(83,3)$ & $192(80,7)$ & \\
\hline Vallásosság & & & & $\mathrm{NSz}$ \\
\hline Igen & $89(25,3)$ & $29(26,6)$ & $60(24,7)$ & \\
\hline $\mathrm{Nem}$ & $263(74,7)$ & $80(73,4)$ & $183(75,3)$ & \\
\hline Alvászavar & & & & $\chi^{2}=8,9 ; p=0,03$ \\
\hline Igen & $94(26,9)$ & $41(37,3)$ & $53(22,1)$ & \\
\hline Nem & $256(73,1)$ & $69(62,7)$ & $187(77,9)$ & \\
\hline
\end{tabular}

$\mathrm{NSz}=$ nem szignifikáns 


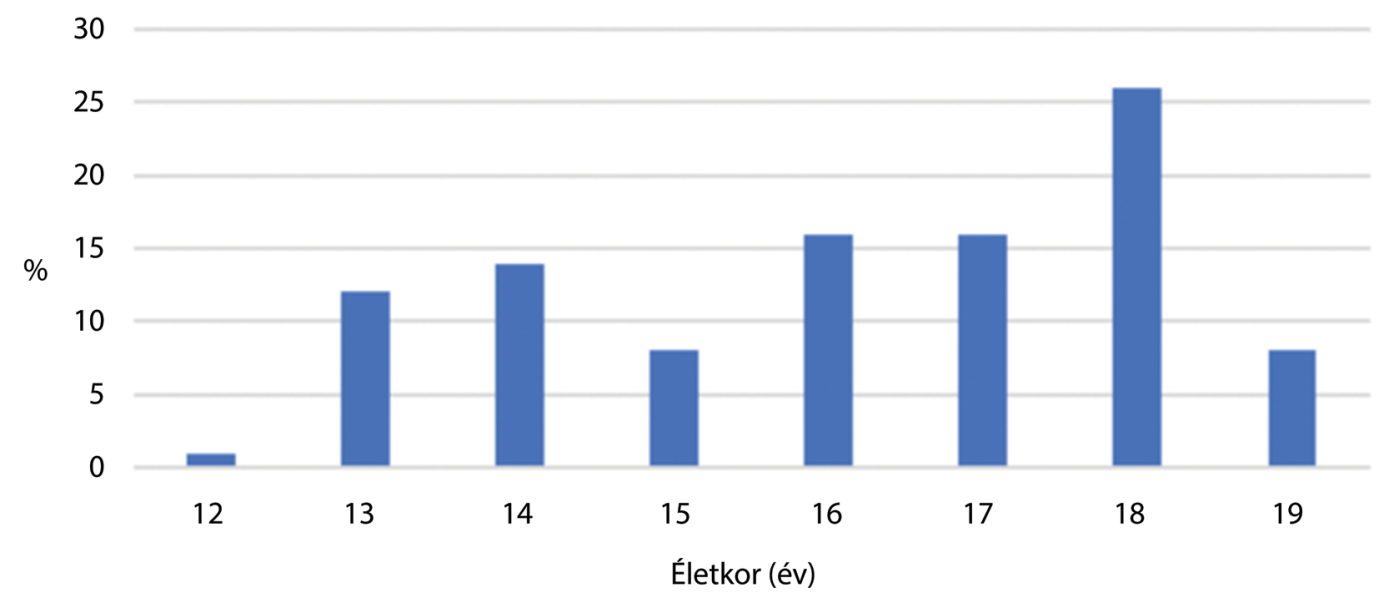

A fentiek mellett a fájdalom miatt orvoshoz fordulások számát is felmértük.

A gyógyszerszedési szokásokra vonatkozó kérdéseknél a gyermekeknek meg kellett jelölniük, hogy alkalmaztak-e gyógyszert az előző hat hónapban, és ha igen, milyen tünetek esetén. A gyógyszerszedés gyakoriságát négy fokozatban lehetetett megadni (ritkán, esetenként, gyakran, rendszeresen). Kutatásunk kitért a gyógyszerek rendelhetőségére is (vényköteles, vagy vény nélkül kapható [over the counter - OTC] készítmény).

\section{Statisztikai módszerek}

A krónikus fájdalom és a gyógyszerszedési szokások elemzésekor deskriptív statisztikai elemzést alkalmaztunk. A változók közötti kapcsolat vizsgálatához a Spearman-féle korrelációt, a két csoport közti különbségek analízisénél a Mann-Whitney-féle U-tesztet, a diszkrét változók analíziséhez a $\chi^{2}$-próbát alkalmaztuk.

A statisztikai elemzéseket az SPSS 17.0 programcsomaggal (SPSS Inc., Chicago, IL, Amerikai Egyesült Államok) végeztük el.

\section{Eredmények}

A vizsgált mintában $110(31,1 \%)$ olyan válaszadót találtunk, akinek a tünetei megfelelnek a krónikus fájdalom definíciójának (1. táblázat). Lányok körében a krónikus fájdalom prevalenciája szignifikánsan magasabb volt a fiúkhoz képest.

Az életkori megoszlás tekintetében a kórképben szenvedők átlagéletkora szignifikánsan magasabb volt a kontrollcsoporthoz képest. A legmagasabb prevalencia a 18 évesek körében (26\%), a legalacsonyabb pedig a 12 éves korosztályban (1\%) volt tapasztalható (1. ábra).

A további mutatók statisztikai elemzésekor nem találtunk szignifikáns különbséget a két csoport között, ugyanakkor az alvászavar szignifikánsan gyakoribbnak mutatkozott a krónikus fájdalommal élők körében (1. táblázat).

\section{A krónikus fájdalom jellemzôi a vizsgált mintában}

A krónikus fájdalom jellemzőit a 2. táblázatban tüntettük fel. A vizsgált mintában a végtagfájdalom prevalenciája volt a legmagasabb. Eredményeinkből kiemelendő, hogy a krónikus fájdalommal élők közel fele a vizsgált időszakban $(46,3 \%)$ a NRS szerint 6 vagy a fölötti erősségű fájdalmat élt meg. A tizenévesek $60 \%$-ának több mint 1 éve volt panasza, és igen magas, 4,6\% volt a folyamatos fájdalom gyakorisága.

\section{Az orvoshoz fordulás gyakorisága összefügg a fájdalom jellemzôivel}

A krónikus fájdalommal élők 30,9\%-a $(\mathrm{n}=34)$ fordult orvoshoz fájdalma miatt az előző három hónapban. Szakemberhez 15,5\% 1-2 alkalommal, 11,8\% 3-5 alkalommal, 3,6\% 5-nél több alkalommal fordult. Problémájával 8,2\% keresett fel „alternatív gyógyászt” (5,5\% 1 alkalommal, 2,7\% 2-4 alkalommal). A krónikus fájdalom jellemzői (fennállásának ideje, erőssége, gyakorisága és időtartama) szignifikánsan befolyásolták az orvoshoz fordulás valószínűségét $\left(\mathrm{r}_{\mathrm{s}}=0,9 ; \mathrm{p}<0,01\right)$.

\section{A gyógyszerszedés prevalenciáját az életkor és a nem befolyásolja}

A tizenévesek $78 \%$-a $(\mathrm{n}=276)$ vett be gyógyszert az előző 6 hónapban, 171 fó $(48,3 \%)$ rendszeresen szedett gyógyszert. A minta egészét tekintve a gyógyszerszedés az életkor előrehaladtával szignifikánsan gyakoribbá vált (3. táblázat).

A lányok gyakrabban alkalmaztak valamilyen gyógyszert, mint a fiúk.

Az iskolatípust tekintve a hatosztályos gimnazistákat összehasonlítva az általános iskolásokkal és a négyosztályos gimnazistákkal, nem találtunk szignifikáns különbséget a gyógyszerszedés gyakoriságában. A lakóhelyet 
2. táblázat |A krónikus fájdalom karakterisztikája a vizsgált mintában

\begin{tabular}{|c|c|c|c|c|c|c|c|c|}
\hline \multicolumn{9}{|l|}{ A fájdalom típusa n (\%) } \\
\hline Fejfájás & \multicolumn{2}{|l|}{ Hasfájás } & Háttájás & \multicolumn{2}{|c|}{ Végtagfájdalom } & \multicolumn{3}{|l|}{ Egyéb } \\
\hline $26(23,9)$ & \multicolumn{2}{|l|}{$21(19,3)$} & $20(18,3)$ & \multicolumn{2}{|l|}{$30(27,5)$} & \multicolumn{2}{|c|}{$12(11,0)$} & \\
\hline \multicolumn{9}{|l|}{ Intenzitás, n (\%) } \\
\hline 1 & 2 & 3 & 5 & 6 & 7 & 8 & 9 & 10 \\
\hline $0(0,0)$ & $5(4,6)$ & $20(18,5)$ & $17(15,7) \quad 16(14,8)$ & $12(11,1)$ & $23(21,3)$ & $9(8,3)$ & $4(3,7)$ & $2(1,9)$ \\
\hline \multicolumn{9}{|l|}{ Mióta áll fenn? n (\%) } \\
\hline & & & 3 hónap & \multicolumn{2}{|c|}{ 4-11 hónap } & \multicolumn{3}{|c|}{1 év vagy több } \\
\hline & & & $9(8,2)$ & \multicolumn{2}{|l|}{$35(31,8)$} & \multicolumn{2}{|c|}{$66(60,0)$} & \\
\hline \multicolumn{9}{|l|}{ Gyakoriság, n (\%) } \\
\hline 1-3-szor egy hónapban & \multicolumn{2}{|l|}{ Hetente } & Hetente többször & \multicolumn{2}{|c|}{ Minden nap } & \multicolumn{3}{|c|}{ Folyamatosan } \\
\hline $45(41,3)$ & \multicolumn{2}{|l|}{$19(17,4)$} & $28(25,7)$ & \multicolumn{2}{|l|}{$12(11,0)$} & \multicolumn{2}{|l|}{$5(4,6)$} & \\
\hline \multicolumn{9}{|l|}{ Időtartam, n (\%) } \\
\hline Kevesebb mint egy óráig & \multicolumn{2}{|l|}{ g 1-2 óráig } & 2-3 óráig & \multicolumn{2}{|c|}{ A nap jó részében } & \multicolumn{3}{|c|}{ Egész nap } \\
\hline $25(22,7)$ & \multicolumn{2}{|l|}{$19(17,3)$} & $19(17,3)$ & \multicolumn{2}{|l|}{$35(31,8)$} & \multicolumn{3}{|c|}{$12(10,9)$} \\
\hline
\end{tabular}

3. táblázat |A gyógyszerszedők eloszlása a különböző csoportokban

\begin{tabular}{|c|c|c|c|}
\hline Gyógyszerszedés & $\begin{array}{l}\text { Igen } \\
\text { Fő }(\%)\end{array}$ & $\begin{array}{l}\text { Nem } \\
\text { Fö (\%) }\end{array}$ & Statisztika \\
\hline & $276(78)$ & $78(22)$ & \\
\hline $\begin{array}{l}\text { Rendszeresen gyógyszert } \\
\text { szedő }\end{array}$ & $171(48,3)$ & $183(51,7)$ & \\
\hline Életkor & & & $\begin{array}{l}\text { Mann- } \\
\text { Whitney } \\
\text { U-teszt = } \\
7767,5 ; \\
\text { p<0,001 }\end{array}$ \\
\hline 12 éves & $1(0,4)$ & $1(1,3)$ & \\
\hline 13 éves & $38(13,8)$ & $20(25,6)$ & \\
\hline 14 éves & $14(11,6)$ & $15(19,2)$ & \\
\hline 15 éves & $44(15,9)$ & $12(15,4)$ & \\
\hline 16 éves & $42(15,2)$ & $10(12,8)$ & \\
\hline 17 éves & $37(13,4)$ & $10(12,8)$ & \\
\hline 18 éves & $66(23,9)$ & $9(11,5)$ & \\
\hline 19 éves & $16(5,8)$ & $1(1,3)$ & \\
\hline Az iskola típusa & & & $\mathrm{NSz}$ \\
\hline Általános iskola & $28(10,1)$ & $14(17,9)$ & \\
\hline Négyosztályos gimnázium & $100(36,2)$ & $18(59,0)$ & \\
\hline Hatosztályos gimnázium & $148(53,6)$ & $46(23,1)$ & \\
\hline Nem & & & $\begin{array}{l}\chi^{2}=7,4 \\
\mathrm{p}<0,01\end{array}$ \\
\hline Fiú & $136(49,3)$ & $52(66,7)$ & \\
\hline Lány & $140(50,7)$ & $26(33,3)$ & \\
\hline Település & & & $\mathrm{NSz}$ \\
\hline Falu vagy tanya & $3(1,1)$ & $1(1,3)$ & \\
\hline Község & $9(3,3)$ & $5(6,4)$ & \\
\hline Kisváros & $40(14,5)$ & $13(16,7)$ & \\
\hline Megyeszékhely & $2(0,7)$ & $0(0,0)$ & \\
\hline Fôváros & $222(80,4)$ & $59(75,6)$ & \\
\hline
\end{tabular}

$\mathrm{NSz}=$ nem szignifikáns tekintve a fơvárosban vagy megyeszékhelyen élőkre sokkal inkább jellemző a gyógyszerszedés, mint a kisebb településen élőkre, ez az összefüggés azonban nem bizonyult szignifikánsnak (3. táblázat).

$\mathrm{Az}$ anya iskolai végzettsége $(\mathrm{t}(\mathrm{df})=-1,0(344) ; \mathrm{p}=$ $0,3)$, valamint a gyermek vallásossága $\left(\chi^{2}=0,2 ; p=0,7\right)$ a mintánkban nem korrelált a gyógyszerszedés gyakoriságával.

A fájdalomcsillapító tekintetében $41,8 \%$-ban a szülő javaslatára, 15,5\%-ban a szülő tudtával történt a gyógyszerszedés, és csak 1,4\%-ban a szülő tudta nélkül.

\section{A gyógyszerszedés valószinüsége nö krónikus fájdalom esetén}

A továbbiakban a fájdalommal élő gyermekek gyógyszerszedési szokásait vetettük össze a kontrollcsoportéval. Eredményeink azt igazolták, hogy a fájdalommal élő tizenévesek közül szignifikánsan többen vettek be gyógyszert, mint az egészséges populációban. Fájdalom miatt a krónikus fájdalommal élók 75,5\%-a ( 83 fó) vett be valamilyen készítményt az előző 6 hónapban, amely arány szignifikánsan magasabb volt, mint a kontrollcsoporté.

A krónikus fájdalommal élő kamaszok a fájdalom mellett a felsorolt többi tünet esetén is (4 kivétellel) szignifikánsan több gyógyszert szedtek, mint a nem fájdalommal élő diákok (4. táblázat).

A fájdalomcsillapító-szedés gyakoriságát tekintve a krónikus fájdalommal élő gyermekek szinte minden csoportban több gyógyszert szedtek, mint a krónikus fájdalomban nem szenvedő társaik (5. táblázat). A kis elemszám miatt azonban statisztikai elemzést nem végeztünk.

A krónikus fájdalom gyógyszerszedési szokásokra gyakorolt hatását tekintve a fájdalom erőssége (Mann-Whitney $\mathrm{U}=8056,4 ; \mathrm{p}=0,5$ ), gyakorisága (Mann-Whitney $\mathrm{U}=9152,6 ; \mathrm{p}=0,9$ ), fennállásának ideje (Mann-Whit- 
Az előző 6 hónap gyógyszerszedési szokásainak összehasonlítás a krónikus fájdalommal élők és az egészséges diákok között

\begin{tabular}{|c|c|c|c|}
\hline & \multicolumn{3}{|c|}{$\begin{array}{l}\text { Gyógyszeralkalmazás } \\
\mathrm{n}(\%)\end{array}$} \\
\hline & $\begin{array}{l}\text { Krónikus } \\
\text { fájdalommal élók }\end{array}$ & Kontroll & Statisztika \\
\hline Összesen & $110(100)$ & $244(100)$ & $\begin{array}{l}\chi^{2}=6,551 \\
p=0,01\end{array}$ \\
\hline \multicolumn{4}{|l|}{ Tünet } \\
\hline Fájdalom & $83(75,5)$ & $125(51,2)$ & $\begin{array}{l}\chi^{2}=18,361 \\
p=0,00\end{array}$ \\
\hline $\begin{array}{l}\text { Gastrointestinalis } \\
\text { panaszok }\end{array}$ & $39(35,5)$ & $39(16,0)$ & $\begin{array}{l}\chi^{2}=17,042 \\
\mathrm{p}=0,00\end{array}$ \\
\hline $\begin{array}{l}\text { Stressz/szorongás/ } \\
\text { alvászavar }\end{array}$ & $23(20,9)$ & $26(10,7)$ & $\begin{array}{l}\chi^{2}=6,684 \\
p=0,01\end{array}$ \\
\hline Hangulati zavar & $8(7,3)$ & $11(4,5)$ & $\mathrm{NSz}$ \\
\hline Fertőző megbetegedés & $40(36,4)$ & $52(21,3)$ & $\begin{array}{l}\chi^{2}=8,931 \\
p=0,00\end{array}$ \\
\hline Krónikus gyulladás & $25(22,7)$ & $25(10,2)$ & $\begin{array}{l}\chi^{2}=9,738 \\
p=0,00\end{array}$ \\
\hline Felső légúti hurut & $70(63,6)$ & $126(51,6)$ & $\mathrm{NSz}$ \\
\hline Láz & $47(42,7)$ & $90(36,9)$ & $\mathrm{NSz}$ \\
\hline Megelőzés & $72(65,5)$ & $134(54,9)$ & $\mathrm{NSz}$ \\
\hline Egyéb & $15(13,6)$ & $12(4,9)$ & $\begin{array}{l}\chi^{2}=12,821 \\
\mathrm{p}=0,00\end{array}$ \\
\hline
\end{tabular}

$\mathrm{NSz}=$ nem szignifikáns

ney $\mathrm{U}=10178,3 ; \mathrm{p}=0,2)$, időtartama (Mann-Whitney $\mathrm{U}=8694,5 ; \mathrm{p}=0,8)$ nem befolyásolta szignifikánsan a gyógyszerszedést. A fájdalom helye nem befolyásolta érdemben, hogy a gyermek milyen gyógyszert alkalmazott (adatot nem közlünk).

A készítmények elérhetősége tekintetében a krónikus fájdalommal élők a hangulatra, a fertőző megbetegedésekre és a krónikus gyulladásra ható gyógyszereket kivéve elsősorban vény nélkül kapható készítményeket alkalmaztak (2. ábra).
5. táblázat |A fájdalomcsillapító-használat gyakorisága az előző 6 hónapban

\begin{tabular}{lcc}
\hline \multirow{2}{*}{ Fájdalomcsillapító-használat } & \multicolumn{2}{|c}{ Gyakoriság, n (\%) } \\
\cline { 2 - 3 } & $\begin{array}{c}\text { Krónikus } \\
\text { fájdalommal élők }\end{array}$ & Kontroll \\
\hline Ritkán & $29(26,4)$ & $68(27,9)$ \\
Esetenként & $30(27,3)$ & $40(16,4)$ \\
Gyakran & $11(10,0)$ & $10(4,1)$ \\
Rendszeresen & $13(11,8)$ & $7(2,9)$ \\
\hline
\end{tabular}

\section{Megbeszélés}

Jelen tanulmányunk célja a krónikus fájdalom prevalenciája mellett a krónikus fájdalommal élő tizenévesek gyógyszerszedési szokásainak felmérése volt.

Vizsgált mintánkban a krónikus fájdalom gyakorisága 31,1\%-nak adódott, ami megfelel a nemzetközi irodalomban található prevalenciaadatoknak $[5,11]$, és összemérhető a korábbi, heti többszöri gyakorisággal jelentkező fájdalmat vizsgáló, 2014. évi magyar egészségmagatartás-vizsgálattal [7].

Kutatásunk megerősítette azokat a korábbi nemzetközi eredményeket is, amelyek alapján a krónikus fájdalom lányok körében gyakoribb. A jelenség a fájdalomérzékelés és -feldolgozás nemi különbségeivel magyarázható [12-14].

Hipotézisünk szerint az életkorral nő a krónikus fájdalom prevalenciája, amit a jelen vizsgálat is alátámaszt. A jelenség mibenléte egyelőre nem egyértelmű, további vizsgálatok szükségesek a különböző életkori sajátosságok tisztázására [3].

A korábbi kutatások alapján az anyai végzettség hatással lehet a fájdalom (elsősorban a fejfájás) kialakulására; jelen vizsgálatunk ezt a kutatási eredményt nem támasztotta alá [15].

A többi vizsgált szociodemográfiai mutató sem mutatott összefüggést a fájdalom prevalenciájával, ami összhangban van a nemzetközi kutatások eredményeivel:

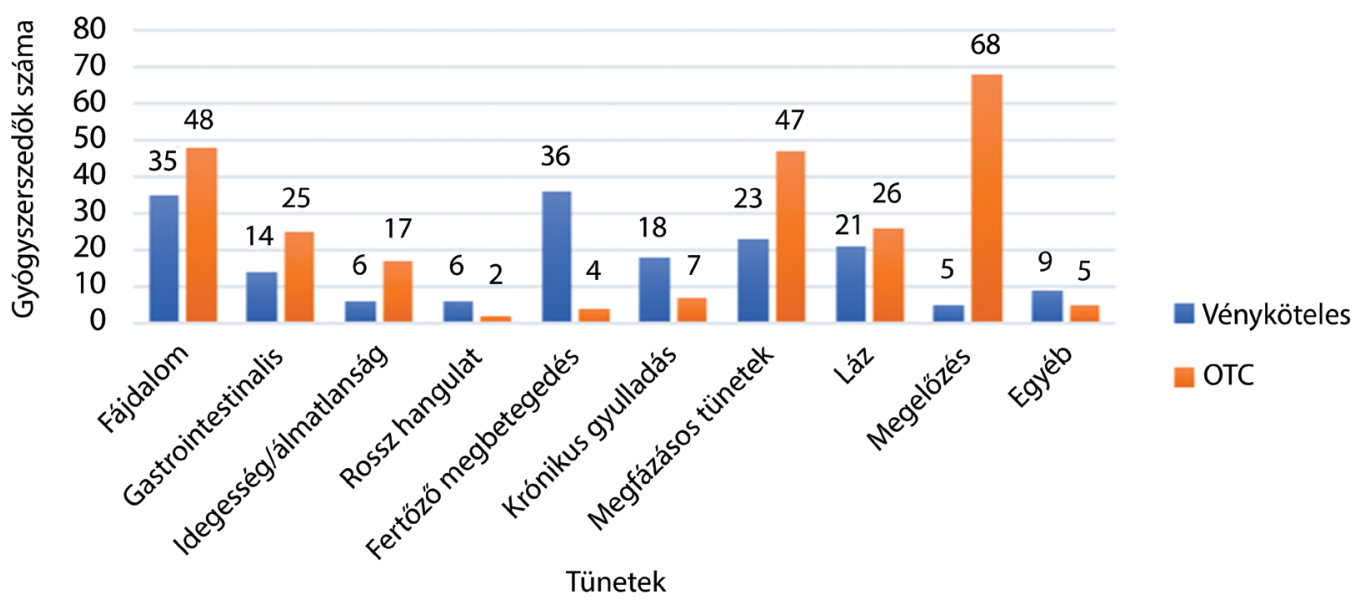

2. ábra Gyógyszerszedési szokások a tünetek és a készítmények elérhetősége tekintetében
OTC = vény nélkül kapható (készítmény) 
amely kutatásokban csak az alacsony szocioökonómiai státusszal találtak kapcsolatot, elsôsorban fejfájós gyermekek körében [3].

Az alvászavar gyakoriságát szignifikánsan magasabbnak találtuk, amely eredményt más kutatók munkássága is megerősíti. Az alvászavar okozta nappali fáradtság hozzájárul a fájdalom okozta teljesítménycsökkenés és az életviteli korlátozottság kialakulásához, és így közvetve szerepe van a krónikus fájdalom fenntartásában [16, 17].

Hipotézisünkkel ellentétben mintánkban nem a krónikus fejfájás, hanem a végtagfájdalom prevalenciája volt a legmagasabb. Összefoglaló tanulmányok alapján a végtagfájdalom gyakorisága elsősorban sportoló gyermekek körében magas, és az életkorral nő [3]. Egy reprezentatív holland kutatás a mi vizsgálatunkhoz hasonlóan a leggyakoribb fájdalomtípusként a végtagfájdalmat írta le a fejfájás és a hasi fájdalom előtt [2]. A korábban említett magyar vizsgálat ugyanakkor a gyakori fájdalom tekintetében a fejfájást találta a leggyakoribb panasznak (végtagfájdalomra vonatkozó kérdés a vizsgálatban nem szerepelt) [7].

Kutatásunk alapján a krónikus fájdalom fennállásának ideje, gyakorisága, intenzitása, időtartama szignifikánsan emeli az orvoshoz fordulás gyakoriságát. Vizsgálatunkkal összhangban Perquin és mtsai is igazoltak összefüggést a fájdalom intenzitása, gyakorisága és az orvoshoz fordulás között [5]. Az összefüggés magyarázata, hogy a fájdalom erőssége és időbeli jellemzői - mint „alarm” tünetek - általában a szülőt és a gyermeket is arra sarkallják, hogy orvosi segítséget kérjenek, így az erősebb és hosszabban, régebb óta tartó fájdalom jobban ösztönözhet az orvos felkeresésére.

A gyógyszerszedés gyakorisága az általunk vizsgált populációban magasabb volt a nemzetközi adatoknál, ami a hosszabb időtartamra való rákérdezéssel magyarázható a korábbi vizsgálatokhoz képest ( 6 hónap, az előző hónap helyett). Eredményeink összefüggést mutattak a női nem, az életkor és a gyógyszerszedés prevalenciája között. Az életkorral külföldi vizsgálatok eredményei szerint is nő az OTC-gyógyszerek alkalmazása és az öngyógyszerezés gyakorisága, különösen lányok körében $[6,17]$.

A nemzetközi irodalom alapján az édesanya iskolai végzettsége jobban befolyásolja a vizsgált jelenséget, mint az édesapáé $[18,19]$.

A jelen vizsgálattal nem tudtunk összefüggést igazolni az édesanya iskolai végzettségével, mint ahogy a vallásossággal sem. Az ezzel kapcsolatos irodalom azonban igen szegényes, ezért további vizsgálatokra lenne szükség a gyógyszerszedés rizikófaktorainak pontosabb tisztázására.

A fájdalommal élő tizenévesek közül szignifikánsan többen vettek be gyógyszert a vizsgált 6 hónapos időszakban, mint a kontrollcsoportban.

A krónikus fájdalom erőssége, gyakorisága, fennállásának ideje, időtartama a vizsgált csoportban nem befolyá- solta szignifikánsan a gyógyszerszedési szokásokat. Perquin és mtsai ugyanakkor a krónikus fájdalom intenzitása és gyakorisága, valamint a gyógyszerfogyasztás prevalenciája között korábban összefüggést igazoltak reprezentatív mintán [5].

A fájdalom lokalizációja a vizsgált személyekben nem befolyásolta érdemben a gyógyszerszedési szokásokat. Holland kutatók vizsgálata ezzel ellentétben azt mutatta, hogy a fül- és fejfájás gyakoribb gyógyszerszedéssel jár, aminek magyarázata az ezen a területen jelentkező fájdalmak kivételesen kellemetlen jellege [5].

Vizsgálatunk erôssége, hogy először vizsgálta krónikus fájdalomban szenvedő magyarországi tizenévesek gyógyszerfogyasztási szokásait. Kutatásunkban került először leírásra, hogy a fájdalom időtartama és fennállásának ideje is befolyásolja az orvoshoz fordulás valószínűségét, és hogy a vallásosság nem befolyásolja a krónikus fájdalom, illetve a gyógyszerszedés előfordulását.

A jelen kutatás érvényességét korlátozza a kis elemszám és a nem reprezentatív, néhány iskolára korlátozódó mintavétel, amely alapján eredményeink nem vonatkoztathatók a magyar tizenéves korosztály egészére. Továbbá a keresztmetszeti vizsgálat jellege miatt okokozati összefüggés adatainkból nem vonható le.

\section{Következtetés}

Kutatásunk eredménye hozzájárul a krónikus fájdalommal élők gyógyszerszedési szokásainak megismeréséhez, és így lehetővé teszi, hogy ezeket is figyelembe véve megfelelő tanácsadásban, terápiában részesüljenek. Továbbá információt szolgáltat a kamaszok gyógyszerfogyasztásáról is, ami további kutatásokat ösztönözhet. A jövőben érdemesnek tartjuk a kutatást reprezentatív mintára kiterjeszteni, hogy adatokat nyerjünk mind általában véve az adolescenskorúak, mind a krónikus fájdalommal élők gyógyszerszedési szokásairól és az azokat befolyásoló rizikófaktorokról.

Anyagi támogatás: A közlemény megírása anyagi támogatásban nem részesült.

Szerzői munkamegosztás: G. K.: Az alapkoncepció kidolgozása, a kézirat megírása, az irodalom összeállítása, adatgyüjtés. M. J.: A kutatási terv elkészítése, a kézirat szerkesztése, szövegezése, a bevezetés, megbeszélés megírása. Gy.-Sz. A.: A kézirat szövegezése. Á. Sz.: A módszertan kidolgozása, statisztikai elemzés, az alapkoncepció kidolgozása, a kézirat szövegezése. A cikk végleges változatát valamennyi szerző elolvasta és jóváhagyta.

Érdekeltségek: A szerzőknek nincsenek a kutatással kapcsolatos érdekeltségeik. 


\section{Köszönetnyilvánítás}

Köszönettel tartozunk a Budapesti Fazekas Mihály Gyakorló Általános Iskola és Gimnázium, a Kossuth Lajos Gimnázium, a Lázár Vilmos Általános Iskola és a Veres Pálné Gimnázium vezetőinek és tanárainak a kutatás lefolytatásában nyújtott technikai segítségért, valamint annak a 354 diáknak, akik a vizsgálatunkban való részvételükkel hozzájárultak kutatómunkánk megvalósításához.

\section{Irodalom}

[1] Harvey AM. Classification of chronic pain - descriptions of chronic pain syndromes and definitions of pain terms. Clin J Pain 1995; 11: 163 .

[2] Perquin CW, Hazebroek-Kampschreur AA, Hunfeld JA, et al Pain in children and adolescents: a common experience. Pain 2000; 87: 51-58

[3] King S, Chambers CT, Huguet A, et al. The epidemiology of chronic pain in children and adolescents revisited: a systematic review. Pain 2011; 152: 2729-2738.

[4] Huguet A, Miró J. The severity of chronic pediatric pain: an epidemiological study. J Pain 2008; 9: 226-236.

[5] Perquin CW, Hazebroek-Kampschreur AA, Hunfeld JA, et al. Chronic pain among children and adolescents: physician consultation and medication use. Clin J Pain 2000; 16: 229-235.

[6] Du Y, Knopf H. Self-medication among children and adolescents in Germany: results of the National Health Survey for Children and Adolescents (KiGGS). Br J Clin Pharmacol. 2009; 68: 599608 .

[7] Németh Á, Költô A. (eds.) Health and health behaviour in school children. A WHO collaborative cross-national study national report 2014. [Egészség és egészségmagatartás iskoláskorban 2014. Az iskoláskorú gyermekek egészségmagatartása elnevezésű, az Egészségügyi Világszervezettel együttműködésben megvalósuló nemzetközi kutatás 2014. évi felméréséről készült nemzeti jelentés.] Nemzeti Egészségfejlesztési Intézet, Budapest, 2016. Available from:http://mek.oszk.hu/16100/16119/ 16119.pdf [accessed: October 15, 2019]. [Hungarian]

[8] Ruiz M. Risks of self-medication practices. Curr Drug Saf. 2010; 5: 315-323.
[9] Büssing A, Michalsen A, Balzat HJ, et al. Are spirituality and religiosity resources for patients with chronic pain conditions? Pain Med. 2009; 10: 327-339.

[10] von Baeyer CL, Spagrud LJ, McCormick JC, et al. Three new datasets supporting use of the Numerical Rating Scale (NRS-11) for children's self-reports of pain intensity. Pain 2009; 143: 223227.

[11] Wiendels NJ, van der Geest MC, Neven AK, et al. Chronic daily headache in children and adolescents. Headache 2005; 45: 678683.

[12] Dengler-Crish CM, Bruehl S, Walker LS. Increased wind-up to heat pain in women with a childhood history of functional abdominal pain. Pain 2011; 152: 802-808.

[13] Walker LS, Stone AL, Smith CA, et al. Interacting influences of gender and chronic pain status on parasympathetically mediated heart rate variability in adolescents and young adults. Pain 2017; 158: 1509-1516.

[14] Chumpitazi BP, Weidler EM, Czyzewski DI, et al. Childhood irritable bowel syndrome characteristics are related to both sex and pubertal development. J Pediatr. 2017; 180: 141-147.el.

[15] Bugdayci R, Ozge A, Sasmaz T, et al. Prevalence and factors affecting headache in Turkish schoolchildren. Pediatr Int. 2005; 47: 316-322.

[16] Roth-Isigkeit A, Thyen U, Stöven H, et al. Pain among children and adolescents restrictions in daily living and triggering factors. Pediatrics 2005; 115: el52-e162. [Erratum: Pediatrics 2005; 115: 1118 .]

[17] Palermo TM, Wilson AC, Lewandowski AS, et al. Behavioral and psychosocial factors associated with insomnia in adolescents with chronic pain. Pain 2011; 152: 89-94.

[18] Dengler R, Roberts H. Adolescents' use of prescribed drugs and over-the-counter preparations. J Public Health Med. 1996; 18: $437-442$.

[19] Bi P, Tong S, Parton KA. Family self-medication and antibiotics abuse for children and juveniles in a Chinese city. Soc Sci Med. 2000; 50: 1445-1450.

(Major János dr., Budapest, Bethesda u. 3., 1146 e-mail: major.janos@bethesda.hu)

"Pro medicina est dolor dolorem qui necat." (Gyógyszer a fájdalom, ha fájdalmat olt ki.)

A cikk a Creative Commons Attribution 4.0 International License (https://creativecommons.org/licenses/by/4.0/) feltételei szerint publikált Open Access közlemény, melynek szellemében a cikk bármilyen médiumban szabadon felhasználható, megosztható és újraközölhető, feltéve, hogy az eredeti szerző és a közlés helye, illetve a CC License linkje és az esetlegesen végrehajtott módositások feltüntetésre kerülnek. (SID_1) 